\title{
A New Start: Two Metres at a Time
}

\author{
Douglas McDougall ${ }^{1}$ (D)
}

Accepted: 27 September 2021 /Published online: 16 October 2021

(C) Ontario Institute for Studies in Education (OISE) 2021

There are a number of points in the year that are considered "new" starts. The one that I find the most exciting is the new start in September (in some jurisdictions, the start to the new school year is in August or January, but they are all exciting to me). At this time of year, there is a great potential for new experiences. The newness exists everywhere: the students in our courses, the courses that we teach, our roles within education, our research questions, and new writing projects.

The 21.3 issue of CJSMTE is also celebrating new and old becoming new. We have restarted the Newsround feature in the journal. This was a feature that appeared during the early inception years of the journal as a way to share news and happenings in the SMT community. After reflections from previous editors (Blades, 2020) and discussions with the editors, we have included this again. Dr. Alexandre Cavalcante of the Ontario Institute for Studies in Education at the University of Toronto is the editor of the Newsround. His inaugural column appears in this issue. There is also a new feature called the Canadian Mathematics Education Matters by Math Editor Egan Chernoff. In his first article, "The Metre as a Metric: Canada's COVID-19 Conversion Kerfuffle", he provides a humourous account of his observations of signs that equate six feet and two metres to describe the social distancing requirements of governments and organizations (Chernoff, 2021). He documents, in written and pictorial form, the poor presentation of the metric system in Canada during the COVID-19 global pandemic.

One of the themes in this issue is the creation and use of science textbooks. Kim et al. (2021) interview Canadian science textbook authors to better understand their hopes for textbooks and some of the challenges they encountered. The textbook authors explained how difficult it was to address social issues in their books due to resistance from science teachers. One of their primary hopes was for teachers to develop and use alternate materials, including textbooks, to engage in discussions about socioenvironmental issues, rather than rely solely on science textbooks. Kim et al. (2021) suggest that it is very difficult to shift the discourse of scientific literacy in textbooks, but they are left with a sense of hope of human agency to make some changes.

Douglas McDougall

doug.mcdougall@utoronto.ca

1 Ontario Institute for Studies in Education, University of Toronto, 252 Bloor Street West, Toronto, ON M5S 1V6, Canada 
Ndumanya et al. (2021) investigate science textbooks being used in South Africa. Their research explored three school science textbooks to better understand the extent to which inquiry-based practices are embedded in the textbooks. They found that the textbook activities and science practices were primarily teacher-directed with very few opportunities for student engagement in the science practices. They also found that textbooks need to be modified to reflect these practices. Both of these articles report on how difficult it is to make changes to science textbooks. As textbooks frequently become the "curriculum" for teachers, this research is very important as new textbooks are written and older ones are adapted to our understanding of how students learn science content and practices.

Langlois et al. (2021) studied college students to learn about their experiences in oral communication about science. The students completed a questionnaire about their perceptions and attitudes about oral communication in science, and 26 of the questionnaire respondents were additionally interviewed. They found that, in addition to standards and contents and the ability to present on a topic in science, context dependance was an important element to be added to the van Aalderen-Smeets et al. (2012) model. They identified other aspects that are subcomponents of an attitude towards scientific oral communication such as anxiety, pleasure, and perception of relevance.

Jin and Kim (2021) explored elementary students' epistemic understanding of scientific argumentation in a grade 5/6 science classroom in Canada. Researchers observed the classroom, collected student work, and interviewed nineteen students and their teacher. It was found that students were aware of their epistemic understandings and that these understandings were refined through social interactions and exposure to new contexts. However, Jin and Kim (2021) also observed that students' performance was not consistent and that some students did not apply their epistemic understandings, even when they were clearly aware of it. Teachers who engage their students in argumentative practice and explicit conversations about argumentation could lead to improving students' epistemic understanding and argumentation skills.

Martin et al. (2021) conducted a survey of 626 teachers to better understand the practices of teaching probability to elementary and secondary school students. They studied the level of education, level of mathematical fluency, level of confidence in their teaching, the planned use of probabilistic approaches, and the use of manipulatives. The results of the study show that these teachers reported a lower level of didactic confidence in the teaching of probability in elementary and secondary school than other mathematics topics, except for teaching statistics at the secondary school level. As we learn more about the confidence of teachers, the authors suggest that classroom observations of teaching of probability will enrich our understanding and seek to better explain the teaching practices in elementary and secondary schools.

Gómez-Blancarte and Miranda (2021) investigate the design of a mathematics professional program on statistics for five in-service secondary school teachers. They use two concepts, participation and reification, as the dimensions of educational design. They explain how these two dimensions interact to allow the teacher to continue to learn within the professional development program. The designers of the program encouraged communication between the researchers in statistics education and the mathematics teachers to discuss the creation of lesson plans and to use the teacher's classroom to learn about the teaching practice needed to implement these lesson plans. Further exploration of participation and reification in the context of teacher practice is one area proposed by the authors.

Proulx and Mégrourèche (2021) describe the teaching experiments that they have done as part of their study of students' mathematical strategies in elementary and secondary school classrooms. The teachers involved in the study have repeatedly commented on the positive impact of class dynamics, specifically focusing on creating a climate that encourages student engagement. The authors use the concept of benevolence to conceptualize the impact of the teaching experiments on the students, classroom climate, and the nature of mathematics. They provide the reader with insights into students' mathematical productions and classroom teaching. 
Jeannotte et al. (2021) investigate the knowledge and teaching practices of primary teachers to promote mathematical reasoning in Québec. Using discourse analysis, the authors highlight keywords, shared routines, and stories about teaching practice. They note that there are two ways of conceiving mathematics reasoning: as a skill to be assessed or a process of understanding. These two ways lead to different foundations and metadiscursive rules, thus creating different routines and introducing conflicts for people in this community. The authors suggest that the mathematics program should be changed to help elementary school teachers to broaden the way they conceive and develop mathematical reasoning in the classroom.

Setyowati et al. (2021) provide a book review on STEM Education across the Learning Continuum: Early Childhood to Senior Secondary (MacDonald et al., 2020). They indicate that there are perspectives and contexts from countries such as Australia, Sweden, the UK, Qatar, and the USA. With a set of empirical papers (nine chapters) and conceptual papers (six chapters), the book provides researchers, teachers, and administrators with how to integrate STEM into early childhood to secondary education.

The editors and staff of CJSMTE hope that your new academic year has brought new insights, energy, questions, and wonder to your professional and personal life. We recognize there is still much uncertainty as we navigate the changing conditions of the COVID-19 pandemic. As we move forward as a community, I hope that the potential for professional growth and academic pursuits motivate you to share your new learnings with us and others through professional and academic journals.

\section{Declarations}

Conflict of interest The author declares no competing interests.

\section{References}

Blades, D. (2020). Newsround: A repetition. Canadian Journal for Science, Mathematics and Technology, 20(4), $780-783$. Chernoff, E. (2021). The metre as a metric: Canada's COVID-19 conversion kerfuffle. Canadian Journal of Science, Mathematics and Technology Education, 21(3). https://doi.org/10.1007/s42330-021-00176-0

Gómez-Blancarte, A. L. \& Miranda, I. (2021). Participation and reification: two basic design principles for mathematics professional development programs. Canadian Journal of Science, Mathematics and Technology Education, 21(3). https://doi.org/10.1007/s42330-021-00175-1

Jeannotte, D., Sampson, S., \& Dufour, S. (2021). Caractérisation du discours mathématique pour l'enseignement associé au raisonnement mathématique d'enseignantes du primaire au Québec: une exploration. Canadian Journal of Science, Mathematics and Technology Education, 21(3). https://doi.org/10.1007/s42330-021-00165-3

Jin, Q. \& Kim, M. (2021). Elementary students' epistemic understandings in their classroom scientific argumentation. Canadian Journal of Science, Mathematics and Technology Education, 21(3). https://doi.org/10.1007/ s42330-021-00166-2

Kim, M., Wagner, D., \& Jin, Q. (2021). Tensions and hopes for embedding peace and sustainability in science education: stories from science textbook authors. Canadian Journal of Science, Mathematics and Technology Education, 21(3). https://doi.org/10.1007/s42330-021-00157-3

Langlois, S., Cormier, C, \& Marec, C-É. (2021). Respecter les normes et posséder un sens du spectacle en communication orale en sciences : les deux aspects du sentiment d'efficacité personnelle d'étudiants postsecondaires en sciences Canadian Journal of Science, Mathematics and Technology Education, 21(3). https://doi.org/10.1007/ s42330-021-00170-6

Martin, V., Thibault, M., \& Roy, N. (2021). Pratiques déclarées d'enseignement des probabilités : enquête auprès de personnes enseignantes du primaire et secondaire au Québec. Canadian Journal of Science, Mathematics and Technology Education, 21(3). https://doi.org/10.1007/s42330-021-00177-z

MacDonald, A., Danaia, L., \& Murphy, S. (Eds.) (2020). STEM Education across the Learning Continuum: Early Childhood to Senior Secondary. Springer. 
Ndumanya, E., Ramnarain, U., \& Wu, H.-K. (2021). An analysis of selected grade 12 physical sciences textbooks for the inclusion of the NGSS science practices. Canadian Journal of Science, Mathematics and Technology Education, 21(3). https://doi.org/10.1007/s42330-021-00169-z

Proulx, J. \& Mégrourèche, C. (2021). Retombées collatérales d'un Teaching Experiment : vers une bienveillance didactique. Canadian Journal of Science, Mathematics and Technology Education, 21(3). https://doi.org/10.1007/ s42330-021-00171-5

Setyowati, Y., Firda, R., \& Kasmita, W. (2021). STEM education: exploring practices across education levels. Canadian Journal of Science, Mathematics and Technology Education, 21(3). https://doi.org/10.1007/s42330-021-00172-4

van Aalderen-Smeets, S. I., Walma van der Molen, J. H., \& Asma, L. J. F. (2012). Primary teachers' attitudes toward science: A new theoretical framework. Science Education, 96(1), 158-182. https://doi.org/10.1002/sce.20467

Publisher's Note Springer Nature remains neutral with regard to jurisdictional claims in published maps and institutional affiliations. 